\title{
PERANAN PERSEPSI MANFAAT SEBAGAI MEDIASI DALAM PENGARUH PERSEPSI KEMUDAHAN PENGGUNAAN DAN KEPERCAYAAN TERHADAP PENGGUNAAN E-COMMERCE PADA APLIKASI TRAVELOKA
}

\author{
Aziziyah \\ Universitas Negeri Surabaya \\ azizia.zee@gmail.com
}

Abstract

\begin{abstract}
As time went on, business development also grew more rapidly. Booking and travel tickets online compliment online marketing. The aims to provide perceived ease of use, perceived usefulness, and trust in consumers to influence the system's level of use at higher consumers. The purpose of this study is to analyze and discuss the effect of perceived ease of use, perceived usefulness, and trust in e-commerce usage. Respondents in this study are consumers who have booked aeroplane tickets in less than one year with a minimum age of 18 years. The sampling method is non-probability sampling, and the sampling technique uses judgmental sampling. The sample used was 220. The data collection technique used in this study was an online questionnaire. Data analysis techniques using path analysis with the AMOS program. This study indicates that perceived ease of use has a positive and significant effect on perceived usefulness. Perceived ease of use has a positive and significant effect on e-commerce. Perceived benefits have a positive and significant effect on the use of e-commerce. Furthermore, trust has a positive and significant effect on the use of e-commerce.
\end{abstract}

Keywords: perceived ease of use, perceived usefulness, actual system use, trust, e-commerce.

\section{PENDAHULUAN}

Perkembangan internet telah membuka cara-cara baru dalam melakukan perdagangan, dengan diikuti kemajuan teknologi dalam bidang informasi pada saat ini berupa website, platform belanja online, shopping apps, dan jejaring sosial sehingga menjadikan dunia semakin mudah dijangkau. Pengguna internet dijadikan target dari e-commerce karena pada saat ini penetrasi pengguna internet di Indonesia terus meningkat. Hal tersebut dibuktikan dengan survei yang dilakukan oleh Asosiasi Penyelenggara Jasa Internet di Indonesia (APJII), di mana penetrasi internet di Indonesia pada saat ini tercatat mencapai $64,8 \%$ dari total penduduk di Indonesia dengan jumlah penetrasi internet terbesar berasal dari pulau Jawa, penetrasi di pulau ini tercatat mencapai 55,7\% dari total penetrasi internet di Indonesia (apjii.or.id, 2018). Perkembangan penggunaan internet di Indonesia memicu pekembangan e-commerce, dalam laporan e-conomy sea 2018 menunjukkan bahwa ekonomi digital Indonesia mencapai Rp 391 triliun dengan kontribusi sebesar 49\%, angka tersebut menjadikan transaksi ekonomi digital Indonesia berada di peringkat pertama di Asia Tenggara (idea.or.id, 2019). Menurut survei Nielsen, rencana pembelanjaan online yang diminati oleh konsumen Indonesia pada saat ini ialah urusan travelling lebih dari setengah konsumen Indonesia melakukan pembelanjaan online untuk kategori travel dengan mencatat proporsi transaksi online sebesar 62\% (nielsen.com, 2018). Pada survei Nielsen juga menunjukkan sekitar setengah dari konsumen Indonesia berencana untuk membeli tiket pesawat secara online sebesar 55\% dalam waktu enam bulan ke depan (nielsen.com, 2014).

Fenomena di atas berdampak pada peluang bisnis dalam membuka online booking tiket dan travel di Indonesia karena dapat memudahkan pengguna ketika ingin berwisata atau berpergian. Ada beberapa situs e-commerce pemesanan tiket dan travel di Indonesia antara lain, Traveloka, Tiket.com, Trivago, Utiket, Nusatrip, dan Pegipegi. Untuk melihat tingkatan merek dapat dilihat pada Top Brand Index (TBI) yang menilai penghargaan tertinggi kepada merek tertentu yang berhasil meraih penilaian teratas dalam tiga kriteria, yaitu mind share, market share, dan commitmend share, dalam hal ini mengenai Top Brand Index pada ketegori Online Booking Tiket dan Travel menunjukkan bahwa Traveloka memiliki prosentase TBI sebesar $45,7 \%$ berbanding jauh dengan para pesaing yang lain, seperti Trivago (6,5\%), Pegipegi $(3,1 \%)$, Tiket.com (2,8\%), dan Agoda (2,3\%). Hal ini menujukkan bahwa Traveloka merupakan Top Travel Company (topbrand-award.com, 2018). 
Aziziyah. Peranan Persepsi Manfaat Sebagai Mediasi dalam Pengaruh Kemudahan Penggunaan dan Kepercayaan terhadap Penggunaan E-Commerce pada Aplikasi Traveloka

Traveloka merupakan perusahaan travel terkemuka di Asia Tenggara yang menyediakan berbagai kebutuhan perjalanan dalam satu platform. Traveloka bekerja sama dengan lebih dari 100 maskapai domestik dan internasional dengan menyediakan lebih dari 200.000 rute penerbangan ke seluruh dunia (traveloka.com, 2018). Selain itu, Traveloka menawarkan beberapa fitur yang bermanfaat dan kemudahan penggunaan bagi konsumen, adapun beberapa fitur yang bermanfaat pada Traveloka, ialah sebagai berikut. (1) Lebih cepat, dengan menggunakan aplikasi Traveloka urusan pemesanan tiket pesawat akan menjadi lebih cepat karena tidak perlu cetak E-ticket. (2) E-ticket tidak akan hilang, karena E-ticket akan terkirim ke E-mail konsumen dan tersimpan dalam Aplikasi Traveloka sehingga tidak akan hilang dan tertinggal. (3) Harga termurah, Traveloka menawarkan harga termurah, di mana Traveloka tidak membebani biaya apapun pada pengguna melainkan melunasi sesuai harga tiket pesawat yang telah dipesan. Selain manfaat yang telah disebutkan, Traveloka juga memberikan kemudahan penggunaan bagi konsumen, yaitu sebagai berikut. (1) Penerbangan atau seat class, hal ini memungkinkan setiap konsumen dapat memilih kelas penerbangan. (2) Easy reschedule. (3) Price alerts. (4) Customer service siap melayani 24 jam. (5) Berbagai macam metode pembayaran (traveloka.com, 2018).

Di sisi lain, meskipun traveloka mendapat predikat Top Travel Company tetapi rating pada kategori situs online booking tiket dan travel yang menunjukkan Traveloka mendapatkan posisi rating terendah dibandingkan dengan para pesaing, di mana Traveloka berada pada posisi keempat dengan perolehan rating $3.3^{*}$ dengan predikat dapat diterima, sedangkan para pesaing memiliki predikat excellent. Hal ini dikarenakan oleh berbagai pengalaman pengguna disertai dengan ulasan buruk yang dirasakan terhadap system dan fitur yang ada pada aplikasi Traveloka (trustedcompany.com, 2018). Hal tersebut menunjukkan tidak ada kesesuaian dengan berbagai fitur yang bermanfaat dan kemudahan penggunaan yang ditawarkan oleh Traveloka kepada konsumen. Menurut Jogiyanto (2007:111), terdapat dua struktur yang dapat memengaruhi dalam menggunakan sistem informasi, ialah persepsi manfaat (perceived usefulness) dan persepsi kemudahan penggunaan (perceived ease of use) yang merupakan sebagai tindakan yang beralasan dalam konteks penggunaan sistem.

Pada survei statshow untuk mengukur kualitas sebuah perusahaan, menunjukkan Traveloka mendapat tingkat kepercayaan 71, keandalan 71, kerahasiaan transaksi 71, dan keamanan 90 dengan rata-rata predikat good, sedangkan para pesaing memiliki predikat excellent pada setiap poin. Hal ini menunjukkan bahwa Traveloka memiliki kualitas yang kurang dibandingkan para pesaing yang lain, seperti pada kualitas kepercayaan (trustworthiness), yang menunjukkan kualitas kepercayaan (trustworthiness) pada Traveloka dinilai masih kurang dibandingkan dengan para pesaing yang lain. (statshow.com, 2018).

Menurut Turban et. al. (2010:187), kepercayaan (trust) adalah salah satu dari beberapa faktor yang dapat memengaruhi pengambilan keputusan pembelian melalui online, kepercayaan (trust) merupakan faktor yang penting dalam bertransaksi melalui online karena ketika konsumen bertransaksi melalui online maka tanpa memerlukan konsumen untuk bertemu secara langsung dengan penjual karena dengan melalui situs website, aplikasi, dan jejaring sosial maka konsumen dan penjual dapat mencapai kesepakatan. Jika kualitas pada perusahaan dinilai masih kurang, maka ketika konsumen melakukan pemesanan online pada perusahaan tersebut akan merasa tidak pasti atau ragu terhadap kualitas perusahaan tersebut. Hal ini menunjukkan bahwa reputasi dari Traveloka yang telah berubah menjadi buruk, disertai ulasan buruk dari pengguna mengenai system dan berbagai fitur pada aplikasi Traveloka tidak berdampak pada penurunan jumlah pemesanan pada aplikasi Traveloka.

Penelitian ini bertujuan untuk mengetahui pengaruh persepsi kemudahan penggunaan dan kepercayaan (trust) melalui persepsi manfaat sebagai variabel mediasi pada penggunaan $e$-commerce pada aplikasi Traveloka. 


\section{KAJIAN PUSTAKA DAN PENGEMBANGAN HIPOTESIS}

\section{Persepsi Manfaat (Perceived Usefulness)}

Persepsi manfaat (perceived usefulness) dijelaskan bahwa sejauh mana seseorang merasa dengan menggunakan sistem tertentu akan meningkatkan kinerja dalam bekerja, dengan ini berarti seseorang akan menganggap teknologi akan bermanfaat untuk sesuatu yang ingin mereka lakukan yang mampu meningkatkan produktivitas kinerja (Davis, 1989). Sedangkan menurut Jogiyanto (2007:114), persepsi manfaat (perceived usefulness) merupakan suatu kepercayaan dalam proses pengambilan keputusan, jika sistem infromasi memiliki manfaat maka seseorang akan menggunakan sistem tersebut, namun jika merasa sistem infromasi tersebut kurang bermanfaat maka tidak akan digunakan. Menurut Kim et. al. (2008), persepsi manfaat merupakan sebuah kesadaran bagi konsumen tentang bagaimana dia akan merasa jauh lebih mudah ketika bertransaksi online melalui situs belanja tertentu. Untuk mengukur variabel persepsi manfaat menggunakan indikator penelitian oleh Davis (1989) dan Suhir (2014), ialah meningkatkan kinerja, bermanfaat bagi pengguna, meningkatkan produktivitas, dan meningkatkan efektivitas.

\section{Persepsi Kemudahan Penggunaan (Perceived Ease of Use)}

Persepsi kemudahan penggunaan (perceived ease of use) dijelaskan bahwa sejauh mana seseorang merasa bahwa dengan menggunakan sistem tertentu akan meminimalkan dari usaha, dengan ini berarti jika dirasa sistem teknologi mudah digunakan maka hambatan bisa diatasi, namun jika tidak mudah digunakan atau rumit maka tidak akan memiliki sikap positif terhadap sistem tersebut (Davis, 1989). Sedangkan menurut Jogiyanto (2007:115), persepsi kemudahan penggunaan (perceived ease of use) merupakan sejauh mana seseorang percaya bahwa dengan menggunakan sistem teknologi tidak akan merepotkan, serta tidak membutuhkan usaha yang lebih pada saat menggunakan sistem tersebut. Wen et. al. (2011) mengatakan sejauh mana seseorang akan merasakan kemudahan dalam berbelanja melalui situs e-commerce, serta akan mendapatkan berbagai informasi produk maupun jasa yang diinginkan. Untuk mengukur variabel kemudahan dalam penggunaan menggunakan indikator penelitian oleh Davis (1989), ialah mudah dipelajari, mudah dipahami, mudah digunakan, interaksi fleksibel, dan efisiensi waktu.

\section{Penggunaan Sistem (Actual system Use)}

Menurut Davis (1989), penggunaan sistem (actual system usage) ialah kondisi ketika pengaplikasian penggunaan pada sistem, di mana seseorang akan merasa senang dalam menggunakan sistem, jika dia merasa bahwa sistem tersebut tidak sulit ketika digunakan dan terbukti dapat meningkatkan produktivitas kinerja yang tercermin dari kondisi pada saat penggunaan. Menurut Jogiyanto (2007:117), penggunaan sistem (actual system usage) merupakan tindakan yang dilakukan oleh seseorang pada konteks penggunaan sistem teknologi informasi dengan perilaku seseorang tersebut sebagai penggunaan sesungguhnya (actual use). Untuk mengukur variabel penggunaan sistem (actual system use) menggunakan indikator penelitian oleh Davis (1989) dan Andyka et. al. (2012), ialah intensitas penggunaan dan frekuensi penggunaan.

\section{Kepercayaan (Trust)}

Menurut Sumarwan (2014:166), kepercayaan (trust) merupakan semua pengetahuan dibenak konsumen terhadap berbagai objek, atribut, serta manfaat dari atribut tersebut. Menurut Mowen \& Minor (2002:312), kepercayaan konsumen (consumer beliefs) merupakan segala pengetahuan yang ada pada benak konsumen dan segala keputusan yang dibuat konsumen tentang sebuah objek, atribut, serta manfaat. Untuk mengukur variabel kepercayaan (trust) menggunakan indikator penelitian oleh Mahkota et. al. (2014) dan Lee \& Wan (2010), ialah percaya transaksi online, percaya online vendor, privasi bisa terjaga, keamanan dalam bertransaksi, dan percaya validitas $e$-ticket.

Adapun rancangan penelitian yang digunakan untuk mengetahui pengaruh persepsi kemudahan penggunaan dan kepercayaan (trust) melalui persepsi manfaat sebagai variabel mediasi pada penggunaan e-commerce pada aplikasi Traveloka, ditunjukkan pada Gambar 1. 
Aziziyah. Peranan Persepsi Manfaat Sebagai Mediasi dalam Pengaruh Kemudahan Penggunaan dan Kepercayaan terhadap Penggunaan E-Commerce pada Aplikasi Traveloka

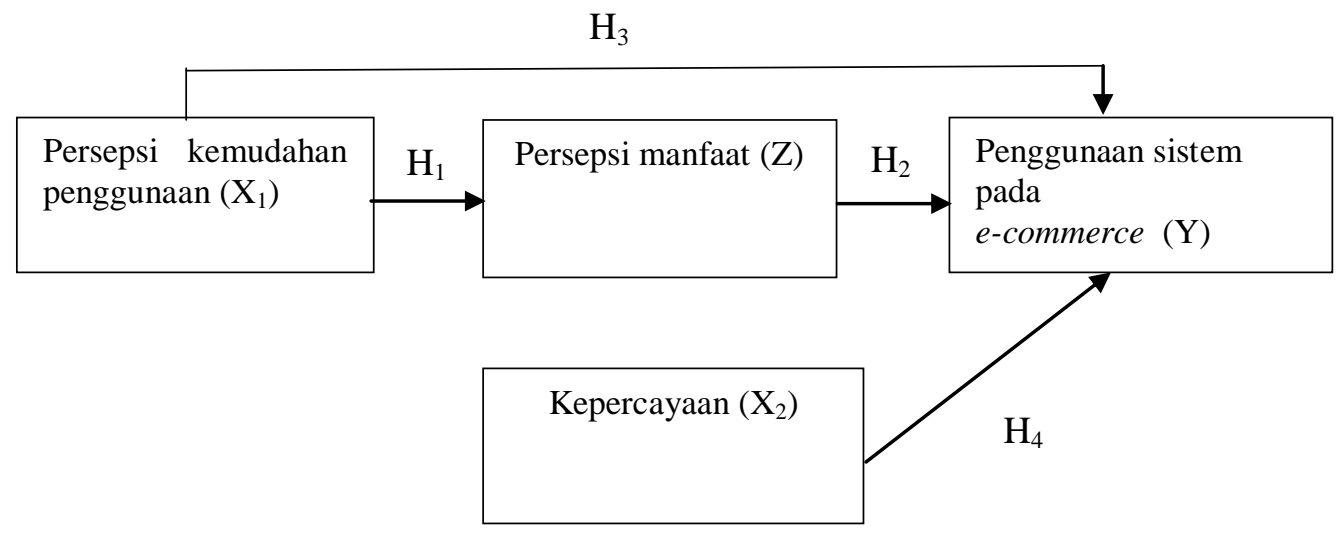

Gambar 1. KERANGKA KONSEPTUAL

\section{Hubungan antar variabel}

Menurut Davis (1989), persepsi kemudahan dalam penggunaan merupakan faktor yang dapat memengaruhi persepsi manfaat. Hal ini juga didukung penelitian Davis et. al. (1993), bahwa terdapat pengaruh positif persepsi kemudahan terhadap persepsi manfaat. Serta mendukung penelitian Sugiarto et. al. (2015), kemudahan penggunaan dapat berpengaruh secara signifikan terhadap manfaat yang dirasakan. Serta menurut Wen et. al. (2011), terdapat pengaruh positif persepsi kemudahan terhadap persepsi manfaat. Sehingga menunjukkan apabila semakin mudah suatu sistem teknologi informasi digunakan maka akan semakin besar pula manfaat yang dirasa oleh pengguna.

H1: Terdapat pengaruh positif antara persepsi kemudahan penggunaan terhadap persepsi manfaat.

Menurut Davis (1989), persepsi manfaat (perceived usefulness) merupakan sebuah kesadaran seseorang terhadap penggunaan sistem tertentu yang dapat meningkatkan kinerja dalam bekerja. Hal ini juga mendukung penelitian Kim et. al. (2008), jika persepsi manfaat sebagai kesadaran tentang sejauh mana seseorang akan mendapatkan hal yang lebih baik dalam berbelanja online melalui situs belanja tertentu. Lebih lanjut Kim et. al. (2008) menunjukkan terdapat pengaruh secara signifikan persepsi manfaat terhadap keputusan penggunaan sistem e-commerce. Lebih lanjut Haryosasongko (2015) menunjukkan persepsi manfaat berpengaruh secara positif terhadap pembelian online. Kemudian Shan et. al. (2010) menunjukkan persepsi manfaat meiliki pengaruh positif terhadap keputusan penggunaan sistem e-commerce.

$\mathrm{H} 2$ : Terdapat pengaruh positif antara persepsi manfaat terhadap penggunaan $e$-commerce.

Menurut Davis (1989), persepsi kemudahan penggunaan (perceived ease of use) merupakan sejauh mana seseorang yakin akan menggunakan sistem teknologi yang digunakan secara mudah, serta bebas dari masalah. Hal ini juga mendukung penelitian Ardyanto (2015), jika kemudahan penggunaan berpengaruh signifikan terhadap keputusan dalam belanja online secara simultan. Lebih lanjut Pudjihardjo \& Wijaya (2015) menunjukkan variabel kemudahan penggunaan memberikan pengaruh yang signifikan terhadap keputusan berbelanja secara online melalui media sosial. Serta menurut Adityo (2011), kemudahan menjadi salah satu hal yang dapat memengaruhi keputusan pembelian secara online.

H3: Terdapat pengaruh positif antara persepsi kemudahan penggunaan terhadap penggunaan $e$ commerce.

Menurut Kim et. al. (2008), keputusan menggunakan e-commerce dipengaruhi oleh kepercayaan (trust) yang merupakan salah satu faktor untuk meningkatkan penggunaan e-commerce karena kepercayaan (trust) merupakan suatu pemahaman dibenak konsumen dalam berbelanja online, dengan kata lain apabila konsumen tidak yakin dengan situs e-commerce maka ia tidak akan memesan produk maupun jasa tersebut. Lebih lanjut Mahkota et. al. (2014) menunjukkan jika kepercayaan (trust) 
berpengaruh signifikan terhadap keputusan berbelanja online, semakin tinggi keyakinan seseorang terhadap vendor situs website dalam berbelanja online berdasarkan atas keyakinan bahwa situs website tersebut akan melaksanakan kewajiban dengan baik maka konsumen akan memutuskan menggunakan situs website tersebut untuk membeli produk maupun jasa mereka. Hasil ini juga mendukung penelitian Ling et. al. (2010), bahwa ada pengaruh positif antara kepercayaan (trust) terhadap keputusan pemebelian secara online.

H4: Terdapat pengaruh positif antara pengaruh kepercayaan (trust) terhadap penggunaan $e$ commerce.

\section{METODE PENELITIAN}

Penelitian ini memakai rancangan riset konklusif yang bermaksud menguji hipotesis (Malhotra, 2009). Adapun lokasi penelitian untuk memperoleh data penelitian ini ialah membagikan angket secara online melalui google form kepada pengguna Aplikasi Traveloka yang berada di Pulau Jawa dengan jumlah 200 responden, serta menggunakan metode non probability sampling dan teknik penarikan sampel secara snowball sampling dengan melakukan wawancara melalui chatting untuk memastikan kecocokan responden dengan karakteristik yang ditetapkan oleh peneliti. Populasi pada penelitian ini bersifat infinite, adapun kriteria responden pada penelitian ini ialah pengguna aplikasi Traveloka yang berada di pulau Jawa yang telah melakukan pemesanan tiket pesawat dalam kurun waktu kurang dari 1 tahun terakhir dengan usia minimal 18 tahun. Adapun pengukuran penelitian ini menggunakan skala likert,. Teknik analisis data yang akan digunakan pada penlitian ini ialah analisis jalur.

Hasil dalam karakteristik responden, pada kriteria menurut jenis kelamin ada 136 responden berjenis kelamin perempuan dan 86 responden berjenis kelamin laki-laki. Pada kriteria asal kota menunjukkan bahwa responden yang paling dominan berasal dari kota Surabaya dengan jumlah 93 responden, berusia antara 18-25 tahun dengan jumlah 203 responden dengan pendapatan perbulan di antara Rp 500.000-Rp 1.000.000 yang paling dominan dengan jumlah 92 responden.

Sebelum data dianalisis perlu dilakukan uji validitas dan reliabilitas. Pada uji validitas dan reliabilitas, peneliti membagikan angket secara online kepada 20 repsonden, di mana 20 responden tersebut bukan termasuk dalam 200 repsonden.

Berdasarkan tabel 1, semua item dalam angket mempunyai r-hitung lebih besar dari r-tabel maka menunjukkan hasil yang valid karena memiliki nilai lebih besar dari 0,361 sehingga item tersebut dapat digunakan sebagai alat ukur pada variabel persepsi kemudahan penggunaan, persepsi manfaat, kepercayaan (trust), dan penggunaan e-commerce. Kemudian pada nilai croncbach's alpha pada setiap variabel juga memiliki nilai lebih besar dari 0,70 sehingga semua item pernyataan bersifat reliabel.

\section{HASIL DAN PEMBAHASAN}

\section{Hasil Analisis Awal}

Hasil uji normalitas pada nilai critical ratio skewness dapat dijelaskan memiliki ditribusi normal karena nilai tersebut terletak di antara rentang nilai $-2,58$ sampai 2,58. Dalam uji normalitas multivariate memiliki nilai sebesar 1,529 dan terletak di antara rentang nilai -2,58 samapi 2,58, dengan hasil tersebut dapat disimpulkan bahwa asumsi multivariate normality dirasa sudah dapat terpenuhi dan dapat digunakan pada estimasi selanjutya. Pada uji linearitas nilai signifikansi persepsi kemudahan pengguna, persepsi manfaat, penggunaan sistem, dan kepercayaan (trust) sebesar kurang dari 0,05, sehingga dapat diartikan bahwa telah memenuhi hubungan antara pepersepsi manfaat, persepsi kemudahan penggunaan, dan kepercayaan (trust) terhadap penggunaan e-commerce. 
Aziziyah. Peranan Persepsi Manfaat Sebagai Mediasi dalam Pengaruh Kemudahan Penggunaan dan Kepercayaan terhadap Penggunaan E-Commerce pada Aplikasi Traveloka

Tabel 1.

HASIL UJI VALIDITAS DAN RELIABILITAS

\begin{tabular}{|c|c|c|c|}
\hline No. & Pernyataan & $\begin{array}{c}\text { Corrected } \\
\text { Item-Total }\end{array}$ & $\begin{array}{l}\text { Croncbach's } \\
\text { Alpha }\end{array}$ \\
\hline \multicolumn{4}{|c|}{ Persepsi Kemudahan Penggunaan } \\
\hline 1. & $\begin{array}{l}\text { Membutuhkan waktu singkat untuk mempelajari penggunaan } \\
\text { aplikasi Traveloka }\end{array}$ & 0,672 & \multirow{9}{*}{0,773} \\
\hline 2. & Petunjuk pemesanan pada aplikasi Traveloka mudah di pelajari & 0,774 & \\
\hline 3. & Tampilam menu pada Aplikasi Trveloka mudah dipahami & 0,745 & \\
\hline 4. & Fitur pada aplikasi Traveloka mudah dipahami & 0,856 & \\
\hline & $\begin{array}{l}\text { Apilkasi Traveloka dapat diakses dengan mobile apapun yang } \\
\text { terkoneksi internet }\end{array}$ & 0,815 & \\
\hline 6. & Tidak mengalami kesulitan dalam mengakses Aplikasi Traveloka & 0,740 & \\
\hline 7. & $\begin{array}{l}\text { Penggunaan bahasa pada aplikasi Traveloka mudah dipahami oleh } \\
\text { konsumen }\end{array}$ & 0,609 & \\
\hline 8. & $\begin{array}{l}\text { Bahasa pada Aplikasi Traveloka dapat diatur sesuai keinginan } \\
\text { pengguna }\end{array}$ & 0,728 & \\
\hline 9. & Aplikasi Traveloka dapat diakses kapan saja dan di mana saja & 0,611 & \\
\hline \multicolumn{4}{|c|}{ Kepercayaan (Trust) } \\
\hline 10. & $\begin{array}{l}\text { Menggunakan aplikasi Traveloka ketika melakukan pemesanan } \\
\text { tiket pesawat }\end{array}$ & 0,821 & \\
\hline & $\begin{array}{l}\text { Traveloka akan memberikan pelayanan yang terbaik ketika } \\
\text { melakukan pemesanan tiket pesawat }\end{array}$ & 0,806 & \\
\hline 12. & Traveloka memberikan infromasi kode booking tiket secara jelas & 0,770 & \\
\hline 13. & $\begin{array}{l}\text { Traveloka memberikan infromasi detail penerbangan (waktu, rute, } \\
\text { dan nomor penerbangan) secara jelas }\end{array}$ & 0,756 & \\
\hline 14. & $\begin{array}{l}\text { Traveloka memberikan informasi detail penumpang (nama, jenis } \\
\text { tiket, info bagasi, dan nomer tiket) secara jelas }\end{array}$ & 0,892 & \\
\hline 15. & Traveloka dapat menjaga privasi konsumen & & \multirow{5}{*}{0,780} \\
\hline 16. & Traveloka menghargai kerahasian data konsumen & 0,864 & \\
\hline & $\begin{array}{l}\text { Traveloka menerima perubahan jadwal penerbangan sesuai } \\
\text { keinginan konsumen }\end{array}$ & $\begin{array}{l}0, / 81 \\
0,793\end{array}$ & \\
\hline 18. & $\begin{array}{l}\text { Traveloka memberikan refund jika terjadi pembatalan pemesanan } \\
\text { tiket pesawat }\end{array}$ & 0,721 & \\
\hline 19. & $\begin{array}{l}\text { Aplikasi Traveloka memberikan konfirmasi pemesanan tiket } \\
\text { pesawat melalui email konsumen }\end{array}$ & 0.575 & \\
\hline \multicolumn{4}{|c|}{ Persepsi Manfaat } \\
\hline & $\begin{array}{l}\text { Aplikasi Traveloka dapat meminimalkan dari kegiatan mengantri } \\
\text { ketika melakukan pemesanan tiket pesawat }\end{array}$ & 0,821 & \multirow{6}{*}{0,797} \\
\hline & $\begin{array}{l}\text { Aplikasi Traveloka dapat mempersingkat waktu ketika ingin } \\
\text { melakukan pemesanan tiket pesawat }\end{array}$ & 0,858 & \\
\hline & $\begin{array}{l}\text { Aplikasi Traveloka sangat bermanfaat pada saat membutuhkan } \\
\text { tiket pesawat }\end{array}$ & 0,713 & \\
\hline & $\begin{array}{l}\text { Aplikasi Traveloka memberikan berbagai informasi terkait } \\
\text { maskapai penerbangan }\end{array}$ & 0,683 & \\
\hline & $\begin{array}{l}\text { Aplikasi Traveloka dapat meningkatkan pengetahuan dalam hal } \\
\text { pemesanan tiket pesawat melalui online }\end{array}$ & 0,822 & \\
\hline & $\begin{array}{l}\text { Traveloka membuat pemesanan tiket pesawat menjadi lebih mudah, } \\
\text { cepat, dan hemat }\end{array}$ & 0,868 & \\
\hline \multicolumn{4}{|c|}{ Penggunaan $E$-commerce } \\
\hline & $\begin{array}{l}\text { Saya akan memilih menggunakan aplikasi Traveloka ketika } \\
\text { melakukan pemesanan tiket pesawat }\end{array}$ & 0,958 & \multirow{2}{*}{0,922} \\
\hline & $\begin{array}{l}\text { Saya sering menggunakan aplikasi Traveloka ketika membutuhkan } \\
\text { tiket pesawat }\end{array}$ & 0,965 & \\
\hline
\end{tabular}

Sumber: Data diolah.

Hasil pada uji outlier yang menunjukkan bahwa nilai mahalanobis distance kurang dari 15,08 atau tidak ada data mahalanobis $d$-square melebihi 15,08 . Serta pada nilai p2 yang tidak menunjukkan 
nilai kurang dari 0,05 sehingga data yang digunakan tersebut dapat dikatakan memenuhi dan sesuai dengan asumsi uji outlier dan data dianggap dapat digunakan untuk estimasi selanjutnya.

Hasil perhitungan ketepatan model menunjukkan sebesar $14 \%$, hasil analisis tersebut menunjukkan bahwa kontribusi model untuk menjelaskan hubungan struktural dari keempat variabel yang diteliti ialah sebesar $0,14(14 \%)$.

\section{Hasil Analisis Path}

Hasil pada Standarized Regression Weights menunjukkan bahwa terdapat perubahan positif pada variabel persepsi kemudahan penggunaan terhadap persepsi manfaat dengan nilai koefisien jalur sebesar 0,201, hal tersebut menunjukkan apabila semakin mudah penggunaan pada apilkasi Traveloka maka persepsi manfaat yang dirasakan akan meningkat pula. Kemudian terdapat perubahan positif variabel persepsi manfaat terhadap penggunaan e-commerce dengan nilai koefisien jalur sebesar 0,265 , hal tersebut menunjukkan apabila semakin baik manfaat yang dirasakan oleh pengguna maka penggunaan aplikasi Traveloka akan meningkat pula. Serta terdapat perubahan positif variabel persepsi kemudahan penggunaan terhadap penggunaan e-commerce dengan nilai koefisien jalur sebesar 0,201 , hal tersebut menunjukkan apabila semakin mudah penggunaan pada aplikasi Traveloka makan keputusan penggunaan aplikasi Traveloka akan meningkat pula. Serta terdapat perubahan positif variabel kepercayaan terhadap penggunaan e-commerce dengan nilai koefisien jalur sebesar 0,167 , hal tersebut menunjukkan jika pengguna percaya pada aplikasi Traveloka maka keputusan penggunaan aplikasi Traveloka akan meningkat pula.

Model diagram jalur dalam penelitian ini ditunjukkan pada gambar 2 dengan dikonversikan ke dalam persamaan model struktural (1) dan (2).

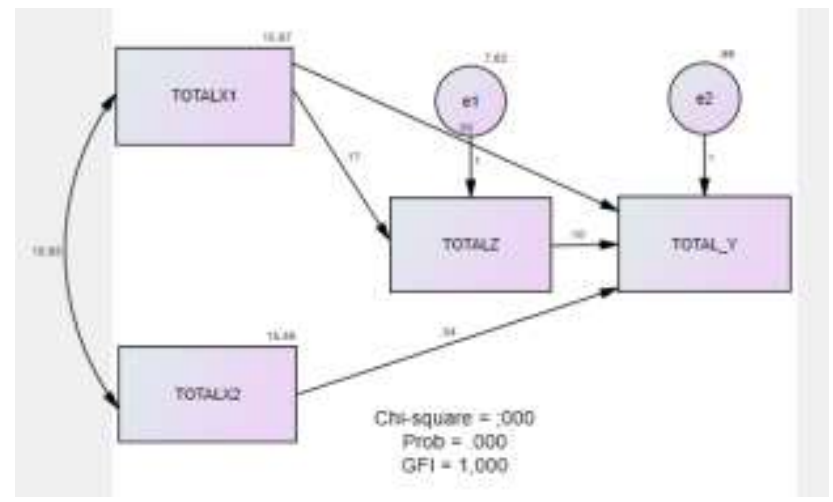

Sumber: Data diolah

Gambar 2. DIAGRAM JALUR

$\mathrm{Z}=\mathrm{b}_{1} \mathrm{X}_{1}+\mathrm{e}_{1}=0,17 \mathrm{X}_{1}+7,62$

$\mathrm{Y}=\mathrm{b}_{4} \mathrm{X}_{2}+\mathrm{b}_{3} \mathrm{X}_{1}+\mathrm{b}_{2} \mathrm{Z}+\mathrm{e}_{2}=0,04 \mathrm{X}_{2}+0,00 \mathrm{X}_{1}+0,10 \mathrm{Z}+0,99$

Keterangan:

$\mathrm{X}_{1}=$ Persepsi kemudahan penggunaan

$\mathrm{X}_{2}=$ Kepercayaan (trust)

$\mathrm{Z}:=$ Persepsi manfaat

$\mathrm{Y}:=$ Penggunaan $e$-commerce

Hasil pada Squared Multiple Correlation atau koefisien determinasi pada penelitian ini ialah seberapa besar perubahan variabel persepsi manfaat disebabkan pengaruh kontribusi pada variabel persepsi kemudahan penggunaan ialah sebesar 0,040 atau pengaruh variabel persepsi kemudahan penggunaan terhadap persepsi manfaat ialah sebesar $4 \%$. Sedangkan perubahan pada variabel penggunaan $e$ commerce disebabkan pengaruh kontribusi pada variabel persepsi kemudahan penggunaan, persepsi 
Aziziyah. Peranan Persepsi Manfaat Sebagai Mediasi dalam Pengaruh Kemudahan Penggunaan dan Kepercayaan terhadap Penggunaan E-Commerce pada Aplikasi Traveloka

manfaat, serta kepercayaan (trust) ialah 0,112 atau 11,2\%.

Tabel 2.

\section{UJI HIPOTESIS}

\begin{tabular}{clcccc}
\hline Hipotesis & \multicolumn{1}{c}{ Variabel } & Estimate & S.E & C.R & P \\
\hline H1 & $\begin{array}{l}\text { Persepsi manfaat } \leftarrow \text { persepsi kemudahan } \\
\text { penggunaan }\end{array}$ & 0,171 & 0,056 & 3,304 & 0,002 \\
H2 & $\begin{array}{l}\text { Penggunaan } e \text {-commerce } \leftarrow \text { persepsi } \\
\text { manfaat }\end{array}$ & 0,099 & 0,025 & 3,949 & 0,000 \\
H3 & $\begin{array}{l}\text { Penggunaan } \text { e-commerce } \leftarrow \text { persepsi } \\
\text { kemudahan penggunaan }\end{array}$ & 0,120 & 0,037 & 3,008 & 0,004 \\
H4 & $\begin{array}{l}\text { Penggunaan } e \text {-commerce } \leftarrow \text { kepercayaan } \\
\text { trust })\end{array}$ & 0,045 & 0,032 & 4,404 & 0,000 \\
\hline
\end{tabular}

Sumber: Data diolah.

Hasil uji hipotesis pada tabel 2 dapat dijelaskan bahwa nilai CR (critical ratio) pada variabel persepsi kemudahan penggunaan terhadap persepsi manfaat ialah sebesar 3,304 $\geq 2,00$ dengan nilai signifikansi sebesar 0,002 yang lebih kecil dari 0,05 atau 5\%, maka hal ini menunjukkan bahwa variabel persepsi kemudahan penggunaan berpengaruh positif dan signifikan terhadap persepsi manfaat. Kemudian pada nilai CR hitung pada variabel persepsi manfaat terhadap penggunaan $e$ commerce ialah sebesar 3,949 $\geq 2,00$ dengan nilai signifikansi sebesar 0,000 yang lebih kecil dari 0,05 atau 5\%, maka hal ini menunjukkan bahwa variabel persepsi manfaat memiliki pengaruh positif dan signifikan terhadap penggunaan e-commerce. Kemudian pada nilai CR hitung pada variabel persepsi kemudahan penggunaan terhadap penggunaan e-commerce ialah sebesar 3,008 $\geq 2,00$ dengan nilai signifikansi sebesar 0,004 yang lebih kecil dari 0,05 atau 5\%, maka hal ini menunjukkan bahwa variabel persepsi kemudahan penggunaan berpengaruh positif dan signifikan terhadap pemggunaan $e$ commerce. Kemudian pada nilai CR hitung antara variabel kepercayaan (trust) terhadap penggunaan e-commerce ialah sebesar 4,404 $\geq 2,00$ dengan nilai signifikansi sebesar 0,000 yang lebih kecil dari 0,05 atau $5 \%$, maka hal ini menunjukkan bahwa variabel kepercayaan (trust) berpengaruh positif dan signifikan terhadap penggunaan $e$-commerce.

Haisl uji mediasi telah terbukti secara parsial (partially mediating), di mana hal tersebut dapat dibuktikan dari hasil uji mediasi antara variabel persepsi kemudahan penggunaan memiliki pengaruh yang signifikan terhadap persepsi manfaat karena memiliki nilai signifikansi sebesar 0,002, kemudian variabel kepercayaan (trust) memiliki pengaruh yang signifikan terhadap penggunaan e-commerce karena memiliki nilai signifikansi sebesar 0,000, kemudian variabel persepsi manfaat memiliki pengaruh yang signifikan terhadap penggunaan e-commerce karena memiliki nilai signifikansi sebesar 0,000 , serta variabel persepsi kemudahan penggunaan terhadap penggunaan e-commerce memiliki nilai siginifikansi sebesar 0,004 . Sehingga hal tersebut memiliki pengaruh yang signifikan karena nilai signifikansi lebih kecil dari 0,05 atau 5\%, dapat dikatakan bahwa penelitian ini dapat terbukti ada mediasi secara parsial (partially mediating).

\section{Pengaruh Persepsi Kemudahan terhadap Penggunaan E-commerce dengan Persepsi Manfaat Sebagai Variabel Mediasi pada Aplikasi Traveloka}

Hasil pada penelitian ini menunjukkan melalui uji analisis jalur ditemukan pengaruh positif antara persepsi kemudahan penggunaan terhadap persepsi manfaat secara langsung, sesuai dengan teori menurut Jogiyanto (2007:112), persepsi kemudahan (perceived ease of use) memengaruhi persepsi manfaat (perceived usefulness), pengguna sistem akan menggunakan sistem jika dirasa bermanfaat, baik sistem tersebut mudah digunakan maupun tidak mudah digunakan, meskipun sistem sulit digunakan maka akan tetap mnggunakan karena sistem tersebut masih berguna. Dalam penelitian ini menunjukkan Traveloka telah mampu memenuhi keinginan pengguna dengan memberikan pengalaman positif dan berkesan melalui pendekatan kemudahan penggunaan melalui 5 dimensi ialah mudah dipelajari, mudah dipahami, mudah digunakan, interaksi fleksibel, dan efisiensi waktu. 
Sehingga hal tersebut menunjukkan jika aplikasi Traveloka dirasa mudah digunakan tanpa kendala apapun, dengan itu pengguna akan merasakan manfaat pada saat menggunakan aplikasi Traveloka dalam melakukan pemesanan tiket pesawat. Pada karakteristik responden perempuan berusia lebih mementingkan kemudahan penggunaan berupa bahasa yang mudah dipahami ketika melakukan pemesanan tiket pesawat melalui aplikasi Traveloka yang akan memengaruhi pengguna untuk merasakan fitur yang bermanfaat pada penggunaan aplikasi Traveloka. Hal ini sesuai dengan berdasarkan item jawaban responden pada angket dengan nilai tertinggi ialah bahasa pada aplikasi Traveloka mudah dipahami oleh pengguna.

Hasil tersebut sesuai dengan teori menurut Davis (1989), persepsi kemudahan penggunaan merupakan faktor yang dapat memengaruhi persepsi manfaat. Lebih lanjut dalam penelitian Sugiarto et. al. (2015), jika kemudahan penggunaan berpengaruh secara signifikan terhadap manfaat yang dirasakan. Serta Wen et. al. (2011) mengatakan terdapat pengaruh yang positif pada persepsi kemudahan terhadap persepsi manfaat.

\section{Pengaruh Persepsi Manfaat terhadap Penggunaan E-commerce pada Aplikasi Traveloka}

Hasil pada penelitian ini juga menunjukkan dengan melalui uji analisis jalur ditemukan ada pengaruh positif antara persepsi manfaat terhadap penggunaan e-commerce secara langsung, sesuai dengan teori menurut Jogiyanto (2007:114), persepsi manfaat (perceived usefulness) merupakan suatu keyakinan dalam proses pengambilan keputusan, jika seseorang merasa yakin bahwa sistem informasi bermanfaat maka dia akan menggunakan. Sebaliknya jika seseorang merasa bahwa sistem informasi tidak bermanfaat maka dia tidak akan menggunakan. Hal tersebut menunjukkan bahwa apabila semakin baik persepsi manfaat yang dirasakan maka penggunaan e-commerce akan meningkat pula, sehingga dapat dijelaskan bahwa semakin yakin seseorang terhadap fitur yang bermanfaat yang ada pada aplikasi Traveloka maka keputusan melakukan pemesanan tiket pesawat melalui aplikasi Traveloka semakin meningkat pula. Pada karekteristik responden yang berpendapatan Rp 500.000 Rp 1.000.000 lebih mementingkan bagaimana konsumen merasa dengan melakukan pemesanan tiket pesawat melalui aplikasi Traveloka dapat mempersingkat waktu pelanggan karena tanpa datang ke biro penjualan tiket pesawat, di mana hal tersebut mengharuskan pelanggan mengelurakan biaya transportasi, sehingga dengan menggunakan aplikasi Traveloka dapat menghemat waktu dan menghemat biaya. Hal ini sesuai dengan berdasarkan item jawaban responden pada angket dengan nilai tertinggi ialah aplikasi Traveloka dapat mempersingkat waktu ketika melakukan pemesanan tiket pesawat.

Hasil tersebut sesuai dengan penelitian Kim et. al. (2008), jika persepsi manfaat berpengaruh positif terhadap keputusan penggunaan e-commerce, persepsi manfaat sebagai kesadaran konsumen sejauh mana seseorang akan mendapatkan hal yang lebih baik dalam bertransaksi online. Serta Haryosasongko (2015) mengatakan jika persepsi manfaat memiliki pengaruh positif terhadap pembelian online. Lebih lanjut Shan et. al. (2010) mengatakan jika persepsi manfaat berpengaruh positif terhadap keputusan penggunaan sistem e-commerce.

\section{Pengaruh Persepsi Kemudahan Penggunaan terhadap Penggunaan E-commerce pada Aplikasi Traveloka}

Hasil pada penelitian ini juga menunjukkan dengan melalui uji analisis jalur ditemukan ada pengaruh positif antara persepsi kemudahan penggunaan terhadap penggunaan e-commerce secara langsung, sesuai dengan teori menurut Jogiyanto (2007:115), jika seseorang merasa yakin bahwa sistem informasi mudah digunakan maka dia akan menggunakan. Sebaliknya jika merasa sistem informasi sulit digunakan maka dia memilih tidak menggunakan. Menurut Davis et. al. (1989), persepsi kemudahan penggunaan (perceived ease of use) sebagai sejauh mana seseorang yakin bahwa menggunakan suatu sistem informasi akan bebas dari usaha. Sehingga dapat diartikan apabila persepsi kemudahan penggunaan meningkat maka keputusan penggunaan e-commerce akan meningkat pula. Hal tersebut menunjukkan bahwa semakin baik kemudahan penggunaan yang dirasakan ketika melakukan pemesanan tiket pesawat maka keputusan menggunakan aplikasi Traveloka semakin tinggi pula. Dalam penelitian ini variabel penggunaan e-commerce diukur dengan menggunakan dua 
Aziziyah. Peranan Persepsi Manfaat Sebagai Mediasi dalam Pengaruh Kemudahan Penggunaan dan Kepercayaan terhadap Penggunaan E-Commerce pada Aplikasi Traveloka

indikator, ialah intensitas penggunaan dan frekuensi penggunaan. Berdasarkan item jawaban responden pada angket dengan nilai tertinggi ialah akan memggunakan aplikasi Traveloka ketika melakukan pemesanan tiket pesawat. Sehingga dapat dikatakan jika aplikasi Traveloka dirasa mudah digunakan, maka pengguna akan lebih memilih menggunakan aplikasi Traveloka ketika membutuhkan tiket pesawat

Hasil tersebut sesuai dengan penelitian Ardyanto \& Riyadi (2015), jika kemudahan berpengaruh signifikan terhadap keputusan dalam berbelanja online secara simultan. Serta Pudjihardjo \& Wijaya (2015) mengatakan jika variabel kemudahan memberikan pengaruh yang signifikan secara simultan terhadap keputusan berlanja online melalui pemasaran di media sosial pada Instagram. Kemudian Adityo (2011) mengatakan jika terkait kemudahan berbelanja online menjadi hal yang paling berpengaruh terhadap keputusan pembelian secara online.

\section{Pengaruh Kepercayaan (Trust) terhadap Penggunaan E-commerce pada Aplikasi Traveloka}

Hasil pada penelitian ini juga menunjukkan bahwa melalui uji analisis jalur ditemukan ada pengaruh positif antara variabel kepercayaan (trust) terhadap penggunaan e-commerce, sesuai dengan teori menurut Turban et. al. (2010:187), kepercayaan (trust) merupakan salah satu faktor yang dapat memengaruhi pengambilan keputusan pembelian secara online. Sehingga dapat dijelaskan bahwa apabila rasa kepercayaan tinggi maka penggunaan e-commerce akan meningkat pula. Hal tersebut menunjukkan bahwa semakin baik rasa kepercayaan pengguna terhadap aplikasi Traveloka maka akan memutuskan menggunakan aplikasi Traveloka dalam melakukan pememesan tiket pesawat secara online. Dari hasil berdasarkan karekteristik responden yang berusia 18-25 tahun lebih mementingkan bagaimana pengguna percaya bahwa Traveloka memberikan konfirmasi terkait tiket pesawat yang telah dipesan melalui $e$-mail yang didaftarkan oleh pengguna pada aplikasi Traveloka. Sehingga dapat dikatakan jika Traveloka memberikan konfirmasi melalu e-mail maka pengguna merasa percaya (trust) dalam menggunakan aplikasi Traveloka pada saat membutuhkan tiket pesawat.

Hasil tersebut sesuai dengan penelitian Kim et. al. (2008), jika keputusan menggunakan sistem $e$ commerce dipengaruhi oleh kepercayaan, di mana kepercayaan merupakan salah satu faktor yang penting dalam meningkatkan penggunaan sistem e-commerce. Serta Mahkota et. al. (2014) mengatakan jika kepercayaan (trust) memiliki pengaruh yang signifikan terhadap keputusan pembelian secara online. Kemudian Ling et. al. (2010) mengatakan jika kepercayaan (trust) berpengaruh positif terhadap keputusan pembelian secara online.

\section{KESIMPULAN}

Berdasarkan penelitian yang telah dilakukan dapat disimpulkan bahwa terdapat pengaruh positif dan signifikan antara persepsi kemudahan penggunaan terhadap penggunaan aplikasi Traveloka dalam melakukan pemesanan tiket pesawat secara online dengan persepsi manfaat sebagai variabel mediasi. Serta persepsi kemudahan penggunaan pada aplikasi Traveloka berpengaruh positif dan signifikan terhadap pengguunaan aplikasi Traveloka dalam melakukan pemesanan tiket pesawat secara online. Kemudian persepsi manfaat yang dirasakan pengguna ketika melakukan pemesanan tiket pesawat berpengaruh positif dan signifikan terhadap penggunaan aplikasi Traveloka. Selaian itu kepercayaan (trust) yang dirasakan pengguna ketika melakukan pemesanan tiket pesawat melalui online berpengaruh positif dan signifikan terhadap penggunaan aplikasi Traveloka.

Lokasi pada penelitian ditentukan pada pengguna aplikasi Traveloka yang berada di pulau Jawa sehingga hasil penelitian ini dirasa kurang sebagai simpulan jawaban. Sehingga diharapkan kepada peneliti selanjutnya untuk menambahkan lokasi yang berbeda agar hasil yang didapatkan dapat lebih dapat digeneralisasikan. Serta objek yang digunakan pada penelitian ini ialah pemesanan tiket pesawat pada aplikasi Traveloka, oleh kerena itu disarankan untuk melakukan penelitian pada jasa lain yang ada pada aplikasi Traveloka dengan segmen yang berbeda seperti reservasi hotel. Hal ini agar dapat mengetahui sejauh mana tingkat persepsi kemudahan penggunaan, persepsi manfaat, dan kepercayaan (trust) terhadap penggunaan aplikasi Traveloka yang dirasakan oleh pengguna pada objek yang berbeda. Selain itu, variabel pada penelitian ini menggunakan faktor perilaku konsumen online pada 
karakteristik konusmen ialah faktor kepercayaan (trust). Penelitian selanjutnya dapat menggunakan faktor kepuasan, sikap, gaya hidup, serta pengalaman agar dapat mengetahui bagaimana tingkat penggunaan pada aplikasi Traveloka yang dirasakan oleh pengguna pada variabel perilaku konsumen online yang berbeda.

\section{DAFTAR PUSTAKA}

Adityo, B. (2011). Analisis Pengaruh Kepercayaan, Kemudahan dan Kualitas Informasi terhadap Keputusan Pembelian Secara Online di Situs Kaskus. Jurnal Manajemen. 3 (4): 1-15

Andyka, R. S., Endang Siti, A., \& Heru, S. (2012). Pengaruh Persepsi Kemudahan dan Persepsi Kemanfaatan Terhadap Penggunaan Youtube Dengan Pendekatan TAM. Jurnal Administrasi Bisnis Universitas Brawijaya. 3 (1): 1-11

Ardyanto, D. (2015). Pengaruh Kemudahan dan Kepercayaan Menggunakan E-commerce Terhadap Keputusan Pembelian Online (Survei Pada Konsumen www.petersaysdenim.com). Jurnal Administrasi Bisnis Universitas Brawijaya. 22 (1): 1-8

Asosiasi Penyelenggara Jasa Internet Indonesia. (2018). Hasil Survei Penetrasi dan Perilaku Pengguna Internet di Indonesia 2018, (https://apjii.or.id/survei, diakses pada 20 Oktober 2018)

Davis, F. D. (1989). Perceived Usefulness, Perceived Ease Of Use, And User Acceptance. MIS Quarterly. 13(3): 319-339. https://doi.org/10.2307/249008

Davis, F. D. (1993). User Acceptance Of Information Technology: System Characteristics, User Perceptions And Behavioral Impacts. In International Journal Of Manmachine Studies. 38 (3): 475-487. https://doi.org/10.1006/imms.1993.1022

Haryosasongko, F. (2015). Pengaruh Persepsi Risiko, Persepsi Kemudahan, dan Persepsi Manfaat Terhadap Minat Pembelian Online Pada Website Lazada.co.id di Kota Malang. Jurnal Ilmiah FEB Universitas Brawijaya. 3 (2): 1-18

Idea.or.id. (2019). Pasar Idea 2019 Hadir Untuk Pertama Kalinya di Indonesia. (https://www.idea.or.id/berita/detail/pasar-idea-2019-hadir-untuk-pertama-kalinya-di-indonesia, diakses pada 03 Maret 2019)

Jogiyanto. (2007). Sistem Informasi Keperilakuan. Yogyakarta: Andi

Kim, D. J., Ferrin, D. L., \& Rao, H. R. (2008). A Trust-Based Consumer Decision-Making Model In Electronic Commerce: The Role Of Trust, Perceived Risk, and Their Antecedents. Decision Support Systems. 44 (2): 544-564. https://doi.org/10.1016/j.dss.2007.07.001

Lee, C. B. P., \& Wan, G. (2010). Including Subjective Norm and Technology Trust In The Technology Acceptance Model: A Case Of E-Ticketing In China. Data Base For Advances In Information Systems. 41 (4): 40-51. https://doi.org/10.1145/1899639.1899642

Ling, K. C., Chai, L. T., \& Piew, T. H. (2010). The Effects Of Shopping Orientations, Online Trust and Prior Online Purchase Experience Toward Customers Online Purchase Intention. International Business Research. 3(3): 63-67. https://doi.org/10.5539/ibr.v3n3p63

Mahkota, A. P., Suyadi, I., \& Riyadi. (2014). Pengaruh Kepercayaan Dan Kenyamanan Terhadap Keputusan Pembelian Online (Studi Pada Pelanggan Website Ride.Inc). Jurnal Administrasi Bisnis (JAB). 8 (2): 1-7

Malhotra, N. K. (2009). Riset Pemasaran. Edisi Keempat Jilid 1. Jakarta: PT Indeks. 
Aziziyah. Peranan Persepsi Manfaat Sebagai Mediasi dalam Pengaruh Kemudahan Penggunaan dan Kepercayaan terhadap Penggunaan E-Commerce pada Aplikasi Traveloka

Mowen, JC dan Michael Minor, 2002. Perilaku Konsumen. Edisi Kelima Jilid 1. Jakarta: Erlangga.

Nielsen.com. (2018). Pembelian grosir online global, (https://www.nielsen.com/id/en/pressreleases/2018/pembelian-grosir-online-global-meningkat-hingga-15persen-dalam-dua-tahunterakhir-diperkirakan-mencapai-usd70-miliar-untuk-fmcg-online/, diakses pada 22 Oktober 2018)

Nielsen.com. (2014). Konsumen Indonesia mulai menyukai belanja online, (https://www.nielsen.com/id/en/press-releases/2014/konsumen-indonesia-mulai-menyukaibelanja-online/, diakses pada 22 Oktober 2018)

Pudjihardjo, M. C., \& Wijaya, H. (2015). Analisa Pengaruh Kepercayaan, Kemudahan, Kualitas Informasi, dan Tampilan Produk Terhadap Keputusan Pembelian Melalui Pemasaran Di Media Sosial (Studi Pada Pengguna Media Sosial di Shapeharve). Jurnal Hospitality dan Manajemen Jasa. 3 (2): 364-379

Shan, S., Hua, F., \& Zeng, Q. (2010). B2C E-Commerce Consumer Decision-Making Model Based On Perceived Benefit And Perceived Risk. International Conference On E-Business And EGovernment. https://doi.org/10.1109/ICEE.2010.561

Statshow.com. (2018). Survei Pengukuran atau Reputasi Kualitas Perusahaan. (https://www.statshow.com/www/Traveloka.com, diakses pada 10 November 2018).

Sugiarto, M., Soeprapto, A., \& Dewanti, I. S. (2015). Technology Readiness dan Model Penerimaan Teknologi Informasi Mahasiswa. 217-226.

Suhir, M. (2014). Pengaruh Persepsi Resiko, Kemudahan Dan Manfaat Terhadap Keputusan Pembelian Secara Online (Survei Terhadap Pengguna Situs WebSite www.kaskus.co.id). Jurnal Administrasi Bisnis (JAB). 8 (1): 1-10

Sumarwan, U. (2014). Perilaku Konsumen dan Penerapannya dalam Pemasaran. Bogor: Ghalia Indonesia.

Top Brand Indeks. (2018). Top Brand Indeks Fase 2 2018, Kategori Situs Online Booking Tiket Pesawat, (https://www.topbrand-award.com/top-brand-index/?tbi_find=Traveloka, diakses pada 28 Oktober 2018)

Turban, Efraim, David King, Dennis Viehland, Jae Lee. (2010). Electronic Commerce a Managerial Perspective. International Edition. Pearson Prentice Hall, New Jersey

Traveloka.com (2018). Tentang Traveloka, (https://m.traveloka.com/id-id/about-us, diakses pada 1 November 2018)

Traveloka.com. (2018). Tiket Pesawat Traveloka, (https://m.traveloka.com/id-id/tiket-pesawat, diakses pada 1 November 2018)

Trustedcompany.com. (2018). Review Pelanggan pada Traveloka, (https://www.trustedcompany.com. Diakses pada 5 November 2018)

Wen, C., Prybutok, V. R., \& Xu, C. (2011). An Integrated Model For Customer Online Repurchase Intention. Journal of Computer Information Systems. 52 (1): 14-23. https://www.researchgate.net/publication/261510555 